Abstracta Iranica

Revue bibliographique pour le domaine irano-aryen

Volume 23 | 2002

Comptes rendus des publications de $\mathbf{2 0 0 0}$

\title{
« Ostād-e bašar ». Našr-e Dāneš, 17, 3 (1379/2000),
} pp. 47-49.

\section{Rédaction}

\section{(2) OpenEdition}

1 Journals

\section{Édition électronique}

URL : http://journals.openedition.org/abstractairanica/35630

DOI : 10.4000/abstractairanica.35630

ISSN : 1961-960X

Éditeur :

CNRS (UMR 7528 Mondes iraniens et indiens), Éditions de l'IFRI

\section{Édition imprimée}

Date de publication : 15 mai 2002

ISSN : 0240-8910

\section{Référence électronique}

Rédaction, « "Ostād-e bašar ». Našrr-e Dāneš, 17, 3 (1379/2000), pp. 47-49. », Abstracta Iranica [En ligne], Volume 23 | 2002, document 240, mis en ligne le 08 février 2010, consulté le 25 septembre 2020. URL : http://journals.openedition.org/abstractairanica/35630; DOI : https://doi.org/10.4000/ abstractairanica.35630

Ce document a été généré automatiquement le 25 septembre 2020.

Tous droits réservés 


\section{« Ostād-e bašar ». Našr-e Dāneš, 17, 3 (1379/2000), pp. 47-49.}

\section{Rédaction}

Compte rendu de l'ouvrage édité sous la direction de Nașrollāh Pūrjavādī et Živa Vesel sur Nāṣīr al-Dīn Ṭūsī. L'auteur montre un intérêt tout particulier pour l'article de Ḥoseyn Ma'ṣūmī Hamadānī.

\section{INDEX}

Thèmes : 10. Histoire des Sciences et des Techniques

\section{AUTEURS}

\section{RÉDACTION}

Directeur de la revue et secrétariats (Paris et Téhéran) 